\title{
Kerklike tug: Pastoraal-kerkregtelik van aard en daarom billik en regverdig? NG Kerkorde, artikel 60.3 'n geesteskind van die Dordtse Kerkorde?
}

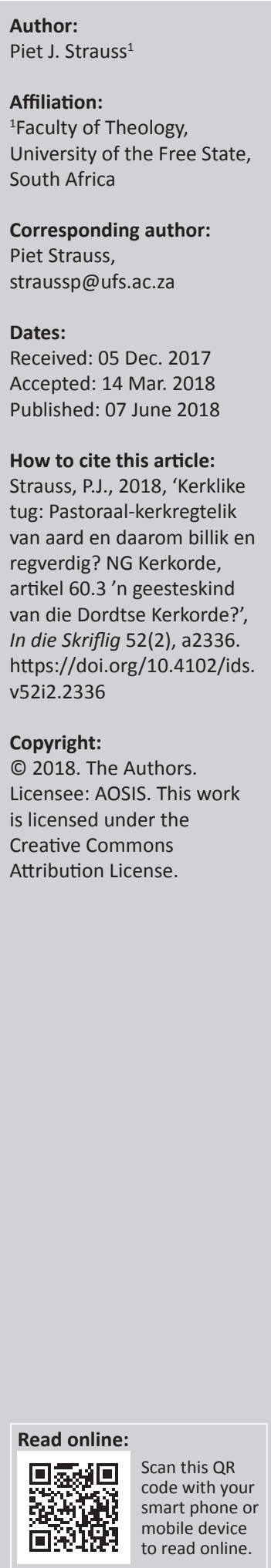

Church discipline: A fair and just pastoral-ecclesiatical act? Is article 60.3 of the Church Order of the Dutch Reformed Church a spiritual offspring of the Church Order of Dordt? Departing from the viewpoint that church discipline is spiritual in nature, article 60.3 of the Church Order of the Dutch Reformed Church states that it should be exercised in a fair and just pastoral-ecclesiatical way. In doing so, this Order should be obedient to the Word of God, the confessions of faith of this church, its church order and the normative character of the church as an institution of society. This requirement, in terms of the formulation of article 60.3, is investigated. In addition, article 60.3 is compared with the Church Order of Dordt to determine whether the former may be regarded as a spiritual offspring of the latter. It is concluded that article 60.3 is indeed scriptural, according to the confessions and determined by the character of the church. It is therefore also an offspring of the Church Order of Dordt.

\section{Probleemstelling}

In die hersiening van sy Kerkorde (Nederduitse Gereformeerde Kerkorde - NGKO) het die Algemene Sinode van die Nederduitse Gereformeerde Kerk (NG Kerk) van 1998 'n nuwe artikel, 59.3, oor die kerklike opsig en tug gemaak: 'Amptelike kerklike opsig en tug is pastoraalkerkregtelik van aard en moet uit 'n Bybelse en geestelike oogpunt billik en regverdig toegepas word' (NGKO 1998:20).

Getrou aan een beginsel vir die uitleg van'n kerkorde - strukturele hermeneutiek, of die kerkorde met homself vergelyk, omdat verskillende artikels mekaar moet aanvul en nie weerspreek nie (Van de Beek 1992:63) - plaas NGKO 1998 in artikels 18, 19 en 59.2 (NGKO 1998:9, 20) die frase 'amptelike kerklike opsig en tug' in perspektief. Hierdie artikels bepaal dat die amptelike opsig en tug in die NG Kerk aan die kerkraad, ring, sinode en Algemene Sinode 'toevertrou' is. Amptelike opsig en tug is nie die informele onderlinge vermaning tussen lidmate nie, maar 'n aanvulling (NGKO 1998:20, artikel 59.2). Amptelike tug in die NG Kerk is tugprosesse van amptelike kerkvergaderings.

In die jongste NGKO (2017:17) word die vroeëre artikel, 59.3, onder nommer 60.3 geplaas. Daarom word daar voortaan na NGKO 2017, artikel 60.3 verwys.

Hierdie bydrae konsentreer op die betekenis en verantwoordbaarheid van 'pastoraal-kerkregtelik van aard', 'billik' en 'regverdig' as rigtingwysers van die amptelike kerklike tug sowel as op die vraag of hierdie bewoording van 'n geestelike nalatenskap van die Dordtse Kerkorde van 1619 (DKO-1619) getuig. ${ }^{1}$ Die vraag is of hierdie bepaling in die verlengde of ' $n$ latere ontwikkeling van die DKO lê - die DKO soos aanvaar deur die Nasionale Sinode van Dordrecht (1618-1619). By die huidige herdenking van hierdie Sinode wat 400 jaar gelede plaasgevind het, is dit 'n belangrike vraag. Op sy beurt was die DKO die eindpunt van die kerkordelike ontwikkeling in die Gereformeerde Kerk in Nederland in die sestiende en sewentiende eeu (Pont 1981:19-189; vgl. Rutgers 1971).

Die Nederlandse Geloofsbelydenis (NGB), een van die Drie Formuliere van Eenheid of belydenisse van geloof soos aanvaar by dieselfde Dordtse Sinode (Donner \& Van den Hoorn s.j.:325), bely in artikel 29 dat die ware Christelike kerk aan drie merktekens uitgeken word: die suiwere bediening van die Woord en die sakramente, en die handhawing van die kerklike tug - merktekens wat

1.Die Dordtse Kerkorde (DKO) van die Dordtse Sinode van 1618-1619 is, na die vertrek van die 23 buitelandse teoloë of afgevaardigdes uit Duitsland, Engeland en Switserland, deur meer as 50 Nederlandse afgevaardigdes in Mei 1619 gefinaliseer (Donner \& Van den Hoorn s.j.:935; Pont 1981:168). 
spruit uit die 'geestelike bestuurswyse (van die kerk) wat ons Here ons in sy Woord geleer het ...' (vgl. NGB, art. 30) (NG Kerk-Uitgewers 1982:30) - 'n geestelike bestuurswyse wat ook in die tughandelinge van die kerk tot uiting moet kom.

As 'n 'nederduitse' (Nederland as 'lage land' van Duitsland) kerk, het die NG Kerk hom sedert sy ontstaan in suidelike Afrika in die jare van 1600 en verder herhaaldelik aan die leer verbind soos 'uitgedruk' in die Drie Formuliere van Eenheid (Strauss 2015:17-24). Gemeet aan sy Kerkorde (NGKO 2017:1, art. 1) en die besluit van die Algemene Sinode van 1998, onderskryf die NG Kerk die formulering van sy geloof in die Drie Formuliere (Nederlandse Geloofsbelydenis of NGB, Heidelbergse Kategismus of HK en Dordtse Leerreëls of DL) omdat - die Latynse quia - hierdie verwoording van die geloof of leer met die Skrif ooreenkom (NGKO 1998:1; Strauss 2006:549-575). Daarmee het die NG Kerk hom ook aan die geestelike bestuurswyse van die kerk verbind soos in die Woord van God en as saak gestel in NGB, artikel 30. 'n Verbintenis waarvan sy Algemene Sinode van 1998 se NGKO 1998, artikel 59.3 'n uitvloeisel moes wees. In die formulering van sy kerkorde is die Algemene Sinode immers besig met hierdie geestelike bestuurswyse.

Teen hierdie agtergrond moet NGKO 2017, artikel 60.3 met sy pastoraal-kerklike tughandeling dus bybels, én by implikasie, belydenismatig wees. Vanuit hierdie normatiewe bronne moet die NG Kerk as 'n geloofs- en liefdesgemeenskap sy opdrag van die kerklike tug uitvoer. In gereformeerde kerktaal is die Bybel die norm van die norme (norma normans) en geloofsbelydenisse die hierop gebaseerde - so glo ons - tweede norm (norma normata) van die kerk (Sadler 1979:185-192). Twee norme wat NGB, artikel 30, by implikasie, ook aan die titel van hierdie artikel oplê.

Gevolglik word die verband tussen NGKO 2017 en die Skrif en die Drie Formuliere ondersoek. 'n Beginsel vir die uitlê van 'n gereformeerde kerkorde is juis die NGKO se verband met die Skrif- en belydeniswaarhede soos bely deur die betrokke kerk - die sogenaamde sistematiese beginsel (Van de Beek 1992:64).

Dit blyk egter ook volgens die NGKO 2017, artikel 60.3 dat die kerklike tughandeling as 'n billike en regverdige pastorale handeling nie in 'n lugleegte los van die samelewing te werk gaan nie. Hoewel die kerk 'n geloofsgekwalifiseerde instelling is waarin dit om die geloofseenheid van Christene gaan soos uitgedruk in hulle belydenisse van geloof as hulle akkoord van kerklike gemeenskap (vgl. die naam Drie Formuliere van Eenheid), vertoon enige kerklike optrede raakvlakke met alle aspekte van die werklikheid. In hierdie proses neem die tughandeling as 'n geloofsgekwalifiseerde handeling die kern van alle ander aspekte van die lewe in diens en maak daarvan norme vir die tughandeling. Vanuit 'n Christelike kosmologie (leer van die skepping) spruit die insig dat alles met alles saamhang en dat wyd aanvaarde norme onder gereformeerdes vir die kerklike tug - soos billikheid en regverdigheid as terme uit die reg (Sadler 1979:182-194) - hierdie samehang vertoon (Fowler 1988:30, 31, 36, 37; Kock 1975:142-144). Enkele voorbeelde staaf hierdie stelling.

Die kern van die liefdesaspek word in die volgende weerspieël: 'n getroue handhawing - in liefde en trou - van die Christelike lewe teenoor ergerlike sondes; toepaslike tugmaatreëls wat rekening hou met die graad van ergerlikheid van die sonde gebou op die norm van geweegde geregtigheid of ekonomiese waarde-afweging; 'n pastorale tughandeling moet harmonieer met die geloofs-, liefdes- en regsgevoel van die gemeente in sy konteks om geestelik opbouend te wees (geestelike harmonie of kuns as 'n psigiese emosie); die tugmaatreël moet lei tot berou en bekering (geestelike oortuigings); sondes wat amptelik getug word, moet met taalbeheersing, konsekwent en in konteks aangetoon word (historiesbeheersde taalvorming); en die tug moet deeglik, sonder haas of sloer met verstaanbare bybelse oogmerke vir veral kerklidmate uitgevoer word. So skep die kerklike tug regsekerheid wat verbind word aan die kern van die geloof, naamlik sekerheid (Kock 1975:53, 144). In hierdie verband wys Coertzen (1998:70, 71) op die beskerming van die regmatige 'regte' van kerklidmate.

Behalwe dat NGKO 2017, artikel 60.3 in harmonie met konstante, normatiewe bybelse waarhede moet wees, moet dit ook die regte begrip vir die geskape werklikheid waarin die kerk as samelewingskring te werk gaan, weerspieël. Kerklike tug hoef nie werklikheidsvreemd, anti-regverdig, post-modernisties-relatief en uit voeling met die regsgevoel van die gemeente te wees om bybels te wees nie. Daarom word die begrippe pastoraal-kerkregtelik, en billik en regverdig as bybels sowel as die samehang daarvan met die res van die lewe ook ondersoek. Hierdie gevolgtrekkings met hulle betekenisse word in die loop van die argument aan die DKO1619 getoets vir 'n moontlike DKO-DNA.

\section{Is kerklike tug as bybelse handeling pastoraal, billik en regverdig?}

Dit is sekerlik so dat die kerklike tug (soos ouerlike tug of tug in skole, ensovoorts) uitgaan van die lewenswaarhede wat in Spreuke 3:12 en Hebreërs 12:7 voorkom: ' ... die Here straf die mens wat Hy liefhet net soos 'n vader doen met sy seun' en 'Verdra die tug as opvoeding, want God behandel julle as sy kinders ...'. Tug gerig op bekering of rehabilitasie soek 'n hartsoortuiging vir dit wat vanuit'n sekere hoek aanvaarbaar is. Hierdie oogmerk moet ten diepste gesoek word vanuit 'n omgee of liefde; 'n omgee wat wil werk aan die een wat getug word as 'n gehoorsame kind van God - waarin en waar ook al. Vir die kerk wat 'n geloofs- en liefdesgemeenskap is (vgl. Joh 20:30-31; 1 Joh; HK Sondag 21 oor die 'gemeenskap van die heiliges of gelowiges' in NG Kerk-Uitgewers 1982:53) wat deur die heilswerk van die drie-enige God tot stand kom, moét die kerklike tug 'n liefdeshandeling vanuit die Christelike geloof wees. Hierdie aanpak word in NGKO 2017, artikel 60.1 kerkordelik aangevoer. Dit verwys na die kerklike 'opsig en tug' as 'n geestelike saak wat by die kerk as 'n geloofs- en liefdesgemeenskap pas - opsig en tug wat 
volgens artikel 60.1 op 'n kerklike wyse met geestelike middele beoefen word (Jansen s.j.:127-135; NGKO 2017:17; Visser 1999:262). Dit word aanvaar dat die woordstam waaruit 'tug' spruit, nader- of regtrek beteken (Bouwman 1985:598-599). Toegepaste kerklike tug kan in Afrikaans ook met die woorde teuel (die stuur van 'n perd) of 'rigting gee' verduidelik word (Kruger, Du Plessis, Spoelstra \& Spoelstra 1966:426) - rigting wat nie energie of inisiatief demp nie, maar reg gekanaliseer en aangewend word.

Hierdie tipering van die kerklike tug as deel van die geestelike taak of opdrag van diekerkas'ngeloofs-en liefdesgemeenskap (broederliefde tussen die gelowiges of kinders van God - 1 Joh 5:1) werk - gestimuleer deur die Reformasie in die jare van 1500 en daarna (Praamsma s.j.:12) - eksplisiet met die kerk as 'n samelewingskring met 'n eie aard of funksie, die Christelike geloof, om dit van ander kringe te onderskei ander kringe wat vanuit hulle eie aard ook na die eer van God moet soek. Reeds by Calvyn was daar 'n onderskeid tussen die tug (straf) van die kerk en die straf van die staat waaraan die burgers van Genève albei gebonde was. Hoewel die kerk deur Skrifgetrouheid en 'n bybelse regverdiging die sondaar moet oortuig omdat hyself 'n geloofs- of geestelike instelling is (vgl. ook Jansen s.j.:127-135; Nauta 1971:358-359) en die staat sy opvatting van billikheid en regverdigheid in algemene belang fisies kan afdwing (Calvyn 1947:479-482), staan albei, volgens Calvyn, onder die tien gebooie. Vir die fisiese dwang van die staat - soos die Woord vir die kerk ${ }^{2}$ - is daar egter 'n grens: billikheid in algemene belang (Sizoo s.j.:555, 559, 562, 576; Strauss 2010:321-322).

Die Bybel onderskei nie daadwerklik tussen kerk en staat nie. Hoewel die Bybel 'n tendensboek met 'n geloofsdoel is - geloof in God en daaruit diens aan God met die hele hart - gee dit ook nie 'n bloudruk vir die taak van die kerk of die kerklike tughandeling nie. Dit is wel so dat die Bybel na die kerk van die Here as 'n geloofsinstelling of die kring van Christengelowiges verwys en rigting gee aan die omvattende Christelike lewe waarvan die georganiseerde kerk 'n deel is. 'n Uitgewerkte model vir die samelewing, geloofsbelydenis of kerkorde kom egter nie in die Skrif voor nie.

Teen hierdie agtergrond kondig DKO, artikel 71 in die sewentiende eeu skerp onderskeidend aan: 'Christelijke straf ...' is 'geestelijk', maar stel die oortreder nie vry van die 'burgerlike gericht of straf' nie. Om sy verwysing na 'geestelik' te verduidelik, wys die DKO op die doel van wat hy noem die 'Christelijke [sedertdien kerklike] straf': die versoening van die sondaar met die kerk en met sy 'naaste' en die wegneem van die ergernis uit die gemeente (afgedruk in Pont 1981:184). Vir die DKO is die georganiseerde kerk as samelewingskring dus óók 'n Christelike geloofs- en liefdesgemeenskap wat op die Woord van God bou.

Die tipering van die kerklike tug as 'geestelik', in onderskeiding van die straf van die staatsowerheid, word

\footnotetext{
2.Smit (1984:127) wys daarop dat die 'volkome koningskap van Christus' in sy kerk ook tot 'uitdrukking gebring' word 'deur die grense van die kerk van die Here by wyse van die Skriftuurlike tug te handhaaf'. Weijland (1965) betitel die onderskrif van sy van die Skriftuurlike tug te handhaaf'. Weijland (1965) betitel die onderskrif van sy
ondersoek na 'Augustinus en de kerklijke tucht' as 'Een onderzoek naar die grenzen van de kerk bij Augustinus ...'.
}

na die DKO-1619 in talle gereformeerde kerkordes met 'n Dordtse konneksie gevolg (Nauta 1971:358; vgl. Van Dellen \& Monsma 1967:288). ${ }^{3}$ Daarmee word die geestelike en kerklike karakter van die kerklike tug 'n aantoonbare DKO-tradisie of lyn. Die DKO wil aan die een kant, die gees waarin die Bybel die kerklike tug benader, ondervang maar aan die ander kant ook blyke gee van die veelkantige, ontwikkelende samelewing waarin die Christengelowige na die donker Middeleeue van ongeveer 500-1500 nC (De Jong 1987:107-154) hom bevind het - 'n samelewing waarin elke kring sy eie funksie vervul en waartoe die Reformasie met sy Soli Deo Gloriabeginsel op alle lewensterreine 'n groot bydrae lewer (Strauss 2010:1-3). NGKO 2017, artikel 60.1 met sy geestelike karakter van 'n geloofs- en liefdesgemeenskap wat die tug op 'n kerklike wyse met geestelike middele toepas, bevind hom hiermee onteenseglik op die afstammingslyn van die DKO-1619.

Volgens Sadler (1979:9) vat Calvyn raak as hy die geestelike aard van die kerklike tug as die tug van 'n Christelike geloofsen liefdesgemeenskap koppel aan die manier waarop die Woord daarin funksioneer, die gees waarin dit geskied, die sake waaroor dit gaan en die mense wat daarin die leiding neem. Gemeet aan Calvyn is die kerklike tughandeling 'n uitvloeisel van die geestelike bestuurswyse van die kerk, van 'n geloofsverband in broederlike liefde.

Sadler (1979) praat van die kerklike tughandeling as die vaderlike en moederlike sorg van die kerk wat 'n kind in liefde van sy dwaalweg wil bekeer - 'n sorg wat 'n deeglike ondersoek na die waarheid loods sowel as 'n gegronde bevinding 'om met tere liefde en belangstelling die oortreders te probeer terugbring van hulle dwaalweë'; 'n sorg wat Skrifgebonde billik en regverdig wil handel, nie haastig of oorywerig is nie en alles behoorlik wil uitpluis. Tussen gelowiges moet'n dwaalweg billik, regverdig en verantwoord aangedui en oorgedra word - anders ontbreek die liefde: 'Tug wat nie deur die oortreder as tug uit liefde ervaar word nie, is geen ware tug nie en sal eerder afstoot as om te behou ...' (Sadler 1979:13-14).

Die pastorale aard van die kerklike tughandeling is 'n gevolg van die geestelike bestuurswyse van die kerk. Hierdie pastorale karakter moet in kerkvergaderings se hantering van alle sake vanuit ' $n$ kerklike perspektief en wyse (Strauss 2010:61; NGKO 2017:7) in alle sake waarby die kerklike ampte betrokke is, gesien kan word. Dit lê in die karakter of aard van 'n goeie herder om met opofferende liefde en toewyding vir sy skape te sorg - 'n sorg wat hulle aan die herder en sy woorde bind nadat Hy hulle van sy sorg en omgee oortuig het. Kerklik word hierdie pastorale aard primêr aan die amp van die ouderling as 'n koning in die geloof gekoppel. Dit word egter ook sigbaar by die sinvolle uitoefening van die profetiese (leraar) en priesterlike (diaken) ampte (vgl. Joh 10 oor Christus as die goeie Herder en Ef. 4:11 wat handel oor herders as gawes van Christus aan sy kerk). Agter die pastorale ontferming van die kerk moet die Here 3.Smit (1984:127) voer aan dat die koningskap van Christus in sy kerk ook gerealiseer word deur die kerklike tug as 'n geestelike handeling. 
Jesus Christus as die goeie Herder, Opdraggewer en Koning van sy kerk deur die beïnvloeding van die Heilige Gees gesien kan word.

\section{NGB, HK en tug as geloofs- en liefdesgehoorsaamheid}

Die NGB en HK beweeg ook in hierdie denkklimaat rondom die kerklike tug. Volgens NGB, artikel 32 is die tug van die kerk daarop ingestel om eendrag en eenheid te bewaar en te bevorder en alles in gehoorsaamheid aan God te onderhou. Gerig op die geestelike bestuurswyse van die kerk vanuit die Woord (NGB, artikel 30), moet tugprosedures en -maatreëls ook 'ooreenkomstig die Woord van God' onderhou word. Die NGB gee egter nie voorbeelde van prosedures en maatreëls vir die tug ooreenkomstig die Woord nie, behalwe 'n vermelding van die ban (NG Kerk-Uitgewers 1982:31; Polman s.j.:60-66). Daarmee erken die NGB waarskynlik dat alle moontlike tuggebruike nie net so in die Skrif aangetref word nie. Wat wel waar is, is dat die NGB die geestelike aard van kerklike tughandelinge soos volgens Calvyn, afstem op die Woord van God wat volgens hom die middelpunt daarvan moet wees (Sizoo s.j.:260-262). Met die gebruik van die woorde eenheid, eendrag en gehoorsaamheid aan God gee die NGB alternatiewe terme vir die bestaan van die kerk as 'n geloofs- en liefdesgemeenskap.

Die HK wei 'n Sondagsafdeling (Sondag 31) aan die kerklike tug. Die verkondiging van die Evangelie en die 'Christelike tug' is volgens die HK die sleutels wat die 'koninkryk van die hemel' vir die mens oop- en toesluit. In die latere byvoeging van Bybeltekste by die HK word hierdie woorde na Matteus 16:19 en Johannes 20:23 herlei. Dit beteken dat ' $n$ gelowige aanvaarding van die Evangelie gelei deur die Heilige Gees die hemel vir die mens oopsluit, maar 'n hardnekkige weiering van dieselfde Evangelie deur ongelowiges wat hulle verhard teen die Woordgetroue kerklike tug, sluit die hemel vir hulle toe. Hierdie sleutelmag spruit uit die geestelike of geloofskarakter van die kerklike tug. Vir die funksionering van hierdie sleutels gebruik die HK Matteus 18:15-17 'As jou broeder teen jou sondig ...' (NG Kerk-Uitgewers 1982:62-63).

Die kern van die saak is dat 'n lewende geloof tot 'n volhardende gehoorsaamheid in alles aan God lei, maar 'n geloof wat net in naam is, lei tot volhardende ongehoorsaamheid en die ban. Boonop gooi die ongelowige self hierdie sleutel van die hemelryk weg. (Veldkamp 1975).

De zondaar wordt dan niet hardhandig buiten de deur geplaatst, maar de kerk verklaart, dat hij zichzelf door zijn onboetvaardigheid buiten de gemeenschap van Christus geplaatst heeft. Maar ook dit is niet het einde der tucht ... Ook deze sleutel [aan die kerk toevertrou] is gemaakt van het goud der liefde ... [die kerk] viert haar hoogste triumf, als zij met deze sleutel de deur voor de berouwvolle zondaar weer mag opendoen. (bl. 105-106)

Ook die HK is nie 'n handboek vir die kerklike tug of tugprosedure nie. Hierdie belydenis is net ' $n$ herhaling van sekere Skrifgedeeltes. Met die koninkryk van die hemel as die erfenis van die gelowiges en die uitsluiting daarvan as 'n bewys van ongeloof, gebruik die HK die kerk as 'n geloofsgemeenskap met die 'sleutels van die koninkryk van die hemel' as sy gereedskap - alles gelei deur die Heilige Gees. Die billikheid en geduld in die opeenvolging van die tugstappe soos uiteengesit in Matteus 18 met die oog op moontlike bekering, is tekenend van die kerk as 'n liefdes- of omgeegemeenskap. Boonop voorsien die HK dat bekeerde sondaars na hulle uitbanning wéér in die gemeente van Christus opgeneem word omdat die kerklike tug ten diepste ingestel moet wees op 'n herstelde verhouding met God (NG Kerk-Uitgewers 1982:63). Omdat die Here ons liefhet, begenadig en met ons 'n nuwe begin maak wat in ons met 'n hartsbekering begin, kan die kerk in sy Naam ook vergewe en ' $n$ nuwe begin maak. Die sondaar moet egter in sy berou duidelik en oortuigend oorkom, 'zijn schuld erkennen en bij de kerk aankloppen met een ootmoedige bede om vergiffenis ...' (Plomp 1969:113).

\section{Kerkordes en skrywers oor die geestelike tug}

Die geestelike karakter van die kerklike tug word deur voorbeelde toegelig in kerkordes wat in die tradisie van die DKO lê.

Die Kerkorde van die Gereformeerde Kerke in Suid-Afrika (GKSA-KO) koppel die geestelike karakter van die kerklike tug soos volgens Calvyn aan die kerklike doel daarvan: die eer van God, die versoening van die sondaar met die kerk en sy naaste en die verwydering van die betrokke 'aanstoot' uit die gemeente (Kruger et al. 1966:423; Visser 1999:261). In hulle kommentaar op die GKSA-KO en om die geestelike karakter van die kerklike tug te onderstreep, onderskei Kruger et al. (1966) dit, soos die DKO, ook van die burgerlike straf. Vir hulle (Kruger et al. 1966) gaan kerklike tug om die opbou van die liggaam van Christus 'deur middel van bekering', terwyl dit in die straf van die owerheid om vergelding gaan. Hulle beklemtoon die geestelike belang van die kerklike tug deur aan te voer dat dit in die Naam van Christus op sy gesag en met geestelike wapens geskied: oortuiging, vermaning, waarskuwing en die ban (Kruger et al. 1966:425-426).

In 'n hersiene Kerkorde van die Christian Reformed Church in North America (CRC-KO), word die geestelike aard van die kerklike tug ook met 'adequate pastoral care' en 'n 'spirit of love and openness' verbind. Wat die CRC-KO betref, moet alle kerklike ampswerk van 'n herderlike of pastorale aanslag getuig (Engelhard \& Hofman 2001:428-430).

Bouwman (1985) noem die kerklike tug kerklik-geestelik en van 'n persoonlike en amptelike aard. Kerklike tug wil deur die Woord nadertrek en herstel. Daarom loop dit uit op teregwysings, vermanings, bestraffings en die geestelikfisiese afsnyding van die gemeente. Vir Bouwman (1985:589-599) komplementeer die Woord van God, die sakramente en die tug mekaar omdat hulle ondenkbaar is 
sonder mekaar. Bouwman koppel ook die funksionering van die Woord, woordtug en ander geestelike maatreëls aan die geestelike aard van die kerklike tug. Omdat die liefde natuurlik billik en regverdig wil wees, sal hy NGKO 2017, artikel 60.3 waarskynlik ook as 'n bepaling in die gees van die DKO aanvaar.

Soos die DKO, stel Jansen (s.j.) die geestelike karakter van die kerklike tug teenoor die uiterlik dwingende straf van die staat. ${ }^{4}$ Die Woord, die sakramente en die tug werk volgens hom geestelik of innerlik. Effektiewe kerklike tug werk deur 'zedelijke overtuiging ..., vermaning en waarschuwing' - 'n kernsaak van gelowig- of kerkwees wat uit die geestelike bestuurswyse van die kerk soos in die NGB, artikel 30 verwoord, vloei. Vir Jansen is kerklike tugmaatreëls soos vermaning, sensuur en die ban, geestelike middels wat gebruik word om te oortuig. Hy (Jansen s.j.:127-135) pleit vir Woord- en Woordgebonde tug met liefde en diskresie, en verwerp juis daarom 'n 'afgewerkte system van tucht' by kerke (vlg. Strauss 2017). Hiermee bevind hy hom in beginsel in dieselfde situasie as die DKO (Pont 1981:168-188) en die Algemene Sinode van die NG Kerk van 1998 wat, in sy aanduiding van vertrekpunte vir die kerklike tug, onder andere NGKO 1998, artikel 59.3 (NGKO 1998:20), ook van 'n gedetailleerde tugreglement ontslae geraak het (NGKO 1998:459-462).

Nauta (1971) bring die kerk se manier om deur oortuiging te werk ook in verband met die geestelike aard van die kerklike tug. Om te slaag, moet die kerklike tug die gewetens van die teikengehoor oortuigend aanspreek - tot so 'n mate dat hulle tot bekering kom. Tug moet so toegepas word dat dit mense oortuig dat hulle hul deur Christus 'laten gezeggen'. Vir Nauta blyk die geestelike karakter van die kerklike tug uit Filippense 2:1-4. Hierin lei hulle gemeenskap, ontferming en barmhartigheid teenoor mekaar en die gemeente om eensgesind te wees, een van hart, in liefde en in strewe na mekaar se belange - sonder selfsug of eie belang (Nauta 1971:358-359).

In hulle uiteensetting van die geestelike aard van die kerklike tug sal die opstellers van hierdie kerkordes en die kerkregtelikes waarskynlik toegee dat NGKO 2017, artikel 60.3 'n geesteskind van die DKO is en in die verdere ontwikkeling van die DKO lê, naamlik dat die kerk as 'n geloofs- en liefdesgemeenskap geroep is om geestelike middele vir die kerklike tug as 'n geestelike saak in liefde te gebruik. Dit is dus 'n proses waarin billikheid en regverdigheid die ander kant van dieselfde munt is.

\section{Algemene geregtigheid ook bybels}

Sadler wys daarop dat die Woord die tug aan reg en regverdigheid verbind. Volgens hom is die Bybel nie 'n handboek vir die kerkreg of kerklike tughandeling nie. Matteus 18:15-17, 2 Korintiërs 13:1 en 1 Timoteus 5:19 bevat 4.Plomp (1969:79) oor Calvyn en die kerklike tug sluit hierby aan as hy van hierdie
soort tug verklaar: 'Ze beoogt geen vergelding, maar berouw en verzoening. Ze is geestelijk van aard.' egter beginsels, grondgedagtes of 'Biblische Weisungen' vir die tughandeling. 'Weisungen' wat hierdie handeling wil rig op liefde, geregtigheid en waarheid (Sadler 1979:12). ${ }^{5}$

Eweredig met die kernbetoog van hierdie bydrae, dui Sadler aan dat die Bybel en aanvaarde beginsels van geregtigheid in die moderne regswêreld - 'n wêreld wat hom binne die Here van die kerk se wette en norme vir die menslike lewe bevind en in sy optrede beperk word deur God se werklikhede soos vervat in sy skeppingswet - versoenbaar en geïntegreerd meewerk in kerklike tugsake. Hoewel die kerklike tughandeling 'n geestelike of geloofsaak is, moet dit ook billik en regverdig toegepas word. Daarom is die gebruik van die geformuleerde reëls van natuurlike geregtigheid 'n 'natuurlike' vereiste of norm vir kerklike tugsake. Terselfdertyd ontbloot die gebruik van hierdie reëls in diens van die kerklike tughandeling die samehang van alles met alles in die lewe. Volgens Sadler, gaan dit om die audi alteram partem- en nemo iudex in causa sua-reëls sowel as die reëls van onpartydigheid en behoorlike aandagbesteding. Dit beteken respektiewelik: om na die ander kant (ter wille van die waarheid na alle kante) ook te luister; niemand is regter in sy eie saak nie (jy kan nie aankla sowel as besluit op 'n amptelike kerklike tughandeling nie); moenie vooraf kant kies of bevooroordeeld wees tydens'n amptelike tugvergadering nie (waarom dan nog 'n ondersoek omdat jy klaar besluit het?); en die saak moet die aandag kry wat dit verdien - soos in die konteks beoordeel (Sadler 1979:51). Sadler, ondersteun deur ander (Coertzen 2003:204 e.v.; Du Plooy 2007:18 e.v.), stel voor dat verwysings hierna in die Bybel gevind moet word omdat die bybelse verhaal juis in ons leefwêreld en omstandighede afspeel. Sadler self wys op Deuteronomium 1:17, 16:19, Johannes 7:51, Handelinge 23:30, 25:16 en Jacobus 1:9. Sonder om die reëls van natuurlike geregtigheid normatief aan te bied, verwys hierdie gedeeltes na destydse voorbeelde van aanvaarde regsbeginsels vir 'n regsaak of 'n ondersoek - voorbeelde van reëls wat steeds erken word: onpartydigheid; die ander kant van die saak ook aanhoor; duidelikheid oor die inhoud van die klag sodat die aangeklaagde hom- of haarself kan verweer; 'n beskuldigde die geleentheid gee om hom- of haarself te verdedig voor 'n bevinding en die onregmatige bevoordeling (by voorbaat of voor enige ondersoek) van sekere mense (Sadler 1979:54).

Sadler (1979) wys op 'n stelling van Wiechers wat meebring dat die kerklike tughandeling as 'n kwasi-judisiële handeling in 'n burgerlike hof beskou word:

'n Kwasi-judisiële handeling is eenvoudig ' $n$ handeling wat lyk op 'n regsprekende, judisiële handeling maar dit nie in werklikheid is nie, omdat die orgaan wat dit verrig nie 'n regsprekende orgaan is nie en nie regsprekende handelinge verrig nie ... (bl. 50)

In die kerk is administratiewe of privaatregtelike handelinge van sogenaamde vrywillige verenigings kwasi-judisieel van

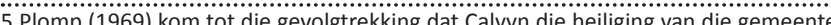
(met (ie tug as' (met die tug as ' $n$ middel) aan sy regverdiging voor God in Christus koppel. Selfs die heiliging van die gemeente het $n$ raakvlak met dit wat reg en regverdig is. Net soos die tug gerig moet wees op dit wat billik en regverdig is voor God téénoor die individuele gelowige en die kerk waarvan hy deel is (Plomp 1969:323). 
aard en kan daarom deur die hof op hersiening geneem word. Dit bring mee dat die hof 'n kerklike uitspraak op twee gronde kan hersien: die kerk se eie kerkorde of prosedurereëls ('n verdraaiing of verontagsaming daarvan deur die kerk self is ultra virus) en die reëls van natuurlike geregtigheid soos reeds verwoord (Sadler 1979:182-192). Dit dui ook daarop dat Suid-Afrikaanse howe normaalweg, soos deur die geskiedenis reeds bewys, hulle daarvan weerhou om tipiese of intern-kerklike uitsprake, gemik op die meriete van geloofs- of etiese sake, te lewer. Howe konsentreer nie graag op die meriete van 'kerkeie' uitsprake nie, maar op die kerklike prosedure of regshandelinge. Op hierdie punt wys Sadler egter op gevalle waar howe wel probeer vasstel het of die leer van die kerk in die betrokke geval so wan- of irrasioneel aangewend is dat dit die aangeklaagde(s) benadeel of verontreg. Die woorde verregaande onredelik ('grossly unreasonable') wat op mala fide of kwade bedoelings by die liggaam wat die tug moet toepas dui, word vir die hersiening deur die hof van so 'n kerklike tughandeling gebruik (Sadler 1979:44-45).

Onder ultra virus het die Appèlhof in die loop van sy uitspraak obiter dictum of terloops in die saak van die Verenigende Gereformeerde Kerk in Suidelike Afrika teen die NG Kerk in Afrika in 1998 daarop gewys dat hofuitsprake rekening moet hou met die eie aard van 'n 'gereformeerd-presbiteriale' kerk en hoe hy homself in sy kerkorde uitdruk. Hoewel die hof kerkvergaderings wat ultra virus optree op hersiening kan neem, moet hy seker maak dat hy die kerk verstaan soos wat die kerk sy eie sake verstaan. Die hof moet die kerkorde, desnoods met die hulp van kundiges, reg lees (Ned Geref Kerk in Afrika v Verenigende Gereformeerde Kerk in Suider-Afrika 1998; Strauss 1999:47).

Genoeg om te sê dat die Appèlhof hiermee aan genoemde sistematiese beginsel vir die uitleg van 'n kerkorde raak. Hierdie hof is dus nie vreemd of vyandig teenoor die kerk as kerk van Christus nie, maar toon respek vir die eie aard daarvan. Daarmee beweeg hy egter ook in die dampkring van NGKO 2017:60.3, naamlik dat die kerklike tug billik en regverdig - ook gemeet aan dit wat die kerk is of probeer wees - toegepas moet word. Boonop toon hy daarmee dat regverdigheid en billikheid ook teenoor die kerk moet geskied in elke situasie waarin die hof gevra word om kerklike tughandelinge op hersiening te neem.

Die ander grond waarop die burgerlike hof die kerklike tughandeling op hersiening kan neem, is natuurlik die reëls van natuurlike geregtigheid. Hier gaan dit oor elementêre regsbeginsels wat 'n voorwaarde is vir alle lewensterreine en waarvan daar al in bybelse tye blyke van erkenning gegee is. Dit is regsbeginsels wat eenvoudig in diens geneem word as 'n lewenskring in terme van sy eie aard en billik en regverdig wil optree (Strauss 2010:1-3). Dit is verder ook regsbeginsels waarvoor die burgerlike hof tydens 'n eksterne hersiening van 'n kerklike beslissing die erkende eenstopkundige is (Sadler 1979:182). 'n Vrywillige vereniging sonder oogmerke wat die toets van die lig kan deurstaan, sal natuurlik geen erg hê aan die reëls van natuurlike geregtigheid in dissiplinêre aksies nie.
Sadler wys daarop dat 'n kwasi-judisiële handeling soos die kerklike tughandeling, in die oog van die burgerlike hof aan sekere geldigheidsvereistes moet voldoen. Hierdie vereistes word bepaal deur algemene billikheidsoorwegings wat in die situasie geformuleer en aangedui word - 'n formulering van billikheid waarin die eie aard van die kerk sowel as kerklike billikheid en regverdigheid in die tyd waarin geleef word prominent moet wees. Kerklike tughandelinge moet billik en regverdig, soos volgens die breë vereistes van NGKO 2017, artikel 60.3 ingestel wees.

'n Kerklike tughandeling moet teen die agtergrond van die kerklike tradisie van die DKO aan die volgende vereistes voldoen: Eerstens moet dit skriftuurlik wees en nie met bybelse konstantes of waarhede bots nie. Een van hierdie konstantes of waarhede is billikheid aan alle mense, afgesien van hulle geloofsoortuiging. ' $n$ Ander is om die waarheid van 'n saak met pastorale geduld bloot te lê. Tweedens moet dit in ooreenstemming wees met die kerkorde en ander kerklike besluite oor die tug waaraan die amptelike vergadering onderworpe is. Die erkenning van hierdie oorweging deur die burgerlike hof blyk uit die vermelde uitspraak van die Appèlhof (Ned Geref Kerk in Afrika v Verenigende Gereformeerde Kerk in Suider-Afrika 1998:14, 15). Derdens moet die kerklike tughandeling aan die reëls van natuurlike geregtigheid voldoen - 'n aanvaarde geregtigheid waarvan mense maklik oortuig word omdat die 'regverdiges' 'n aanvoeling daarvoor het (Sadler 1979:51; Strauss 2010:109-117). ${ }^{6}$

Twee opmerkings vloei uit hierdie kort opsomming: Die eerste is dat die kerklike tug 'n regskant het wat sy geestelike aard komplementeer - 'n kant wat met die kern van hierdie handeling geïntegreer is en meewerk aan die geestelike aard van 'n tugondersoek. Die tweede is dat 'n kerklike tughandeling op grond van die ultra virus-beginsel en die verontagsaming van die reëls van natuurlike geregtigheid aan hersiening in 'n burgerlike hof blootgestel is. Die kerklike tughandeling is wel pastoraal-kerklik van aard, maar dit beteken nie dat hy hom kan losmaak van 'n basiese regverdigheid of billikheid nie.

Gelet op die inhoud van die Woord, die gereformeerde belydenisse en die kerkorde is dit slegs die Woord en die NGKO wat die prosedure vir die tughandeling uitstippel. ${ }^{7}$ Die NGB en HK verwys na die noodsaak en plek daarvan, maar rep geen woord - naas die HK se nasê van Matteus 18:15-17 - oor prosedure nie. Daarom fouteer NGKO (1998:20) as hy in 'n emosionele herwaardering van die Drie Formuliere van Eenheid bepaal dat die tug volgens die voorskrifte van die Woord, die belydenis, die kerkorde en ander besluite van die kerk uitgevoer moet word. In die waardering daarvan deur die Algemene Sinode van 1998 word 'n onkunde oor die inhoud van die Drie Formuliere (die ekumeniese belydenisse bely oor God-Drieënig en nie die kerklike tug nie [Jonker 1994:4-5]) blootgelê wat afbreek doen aan hierdie waardering.

6.Spreuke 21:15 sê kort en kragtig 'As daar reg geskied, is mense wat reg doen, bly, en staan die wat onreg doen, verskrik ...'.

7.Die HK verwys wel na Matteus 18:15-17, maar gee geen addisionele ordebepalings nie. 


\section{Bronne vir NGKO 2017, artikel 60.3}

Met die Woord as norma normans, die Drie Formuliere van Eenheid as norma normata en die prinsipiële samehang van die kerk as 'n geloofsverband met die res van die samelewing en lewe, word NGKO 2017, artikel 60.3 geregverdig en nie weerspreek nie. Inteendeel, artikel 60.3 is juis 'n gevolg van die norme vir die kerklike tug wat hulle uit hierdie bronne aandien: 'amptelike kerklike opsig en tug is pastoraal-kerklik van aard en moet uit 'n Bybelse en geestelike oogpunt billik en regverdig toegepas word'.

Dat die amptelike kerklike tug of die tug van amptelike kerkvergaderings pastoraal-kerklik moet wees soos aangetoon, pas by die pastorale karakter van die amp van die ouderling en van kerklike optrede - in onderskeiding van dié van die staat. Dit gaan hier om die bybelse beeld van herders en skape; om die herderlike bymekaarmaak van die skape (die kerk) in gehoorsaamheid aan die Woord van God; om 'n liefdevolle versorging van skape deur hulle met Woord en Gees nader te trek en geestelik te bind; om 'n binding te bewerkstellig waarop die skape van harte positief antwoord en wat meebring dat hulle individueel en gesamentlik die waarhede van die Woord en die belydenis as lewensankers en -rigters omarm. Kerklike tug, soos die res van die arbeid van die kerk, trek en behou die gelowiges op die lang duur deur innerlike (geloofs-)oortuiging.

Die pastorale karakter van die amptelike kerklike bediening is - sonder om tekste uit te sonder - op die Bybel begrond.

Dat die kerklike tug as 'n geestelike of geloofshandeling uit 'n bybelse oogpunt ook billik en regverdig moet wees word ook gemotiveer deur die betoog tot dusver. Aan die een kant moet herderlike sorg billik en regverdig wees omdat dit deur die liefde gedryf word. Aan die ander kant word aangedui dat die kerk in samehang met die res van die lewe en samelewing ook 'n regskant het - 'n regskant wat die geloofsaard van die kerk moet dien. ${ }^{8}$ Hieruit ontstaan Kerkreg as 'n teologiese vak gerig op die regskant van die kerk - 'n vak wat onder meer met kerkordes as kerklike prosedures te doen het.

Dieselfde samehang blyk uit ander dele van NGKO 1998. Dit is 'n samehang wat 'n gegewe is omdat dit in die geskape lewe die stand van sake is. Sonder om oor die meriete daarvan te argumenteer, dui die volgende artikels van NGKO 1998 ook op hierdie samehang:

Artikel 12 noem die kerkraad of kerkverband die 'werkgewer' van die predikant en konsentreer op die diensverhouding van die kerk met die predikant. Die pasaanvaarde arbeidswetgewing in Suid-Afrika speel hierin 'n stimulerende rol. Die term werkgewer as 'n nie-kerklike term - dit is nie 'n nie-Christelike term nie - word so vir die eerste keer in NGKO opgeneem. Ander gereformeerde kerke in Suid-Afrika volg egter nie hierdie voorbeeld nie, omdat hulle oortuig is dat billike, tipies kerklike arbeidspraktyke in elke geval aan die 8.Plomp (1992:38-40) noem Kerkreg 'n dienende of 'diensrecht'. eise van die staat vir algemene billikheid voldoen en deur die hof as 'n privaatregtelike burgerreg van die kerk as instelling erken word (vgl. Visser 1999). Hiernaas praat NGKO, artikel 21 van 'n kerklike perspektief in onderskeiding van die perspektief van ander kringe in die samelewing (NGKO 1998:9). Hierdie onderskeiding veronderstel dus 'n basiese kennis van die res van die samelewing. Daarby bepaal NGKO, artikel 65 die houding van die NG Kerk teenoor die staat en gebruik hy hiervoor, naas bybelse eksegese, neo-Calvinistiese wysgerig-sosiologiese insigte afgestem op die eie aard van kerk sowel as staat (NGKO 1998:26; Strauss 2010:125-130). Dieselfde waarnemings kom voor by NGKO 1998, artikels 66 en 67 wat oor die NG Kerk en maatskaplike organisasies, vrye verenigings en nie-kerklike onderwys handel (NGKO 1998:26). Die slotsom: NGKO ontsnap nie aan raakvlakke met die lewe en die res van die samelewing nie. Dit is daarom nie vreemd of onkerklik om te bepaal dat die kerklike tughandeling billik en regverdig moet wees nie.

Studiestukke voor die destydse Algemene Regskommissie van die Algemene Sinode wat tot die veranderings aan NGKO 1998 gelei het, bevestig hierdie neo-Calvinistiese wysgerig-sosiologiese invloed op NGKO, artikel 59.3 (NGKO 1998:20). Onder datums 27 Februarie 1997 en 05 Maart 1998, in aanloop tot die Sinode van 11-17 Oktober 1998 (vgl. NGK 1998), word die voorgestelde artikel 59.3 so geformuleer: 'Hoewel kerklike opsig en tug in sy kern nie juridies van aard is nie, moet dit uit 'n Bybelse en geestelike oogpunt regverdig toegepas word' (NGKO 1998:20).

Die woorde kern, juridies en aard plaas NGKO in die dampkring van die woordgebruik van die twintigste-eeuse Christelike Wysbegeerte soos in Nederland, Suid-Afrika en elders. Daarby is NGKO artikel, 59 deel van 'n hersiene NGKO 1962 wat aanvanklik in artikels 65-68 met terme soos soewerein in eie kring en selfstandig in eie bevoegdheid juis uit hierdie waters gedrink het (NGKO 1962:14-15; Strauss 1993:3-5) - 'n historiese aanloop tot NGKO 1998, artikel 59.3 en daarmee saam NGKO 2017, artikel 60.3 wat hierdie dampkring van sy inhoud bevestig.

Die vraag wat oorbly is: Lê NGKO 2017, artikel 60.3 in die verlengde van die DKO? Is hierdie artikel 'n geesteskind van die $\mathrm{DKO}$ ?

\section{Is NGKO 2017, artikel 60.3 ten slotte 'n geesteskind van die DKO?}

'n Studie van die DKO, artikel 71 in sy verband skep die indruk van 'n minder ontwikkelde onderskeibare eie aard van die lewenskringe. Die 'Christelijke straf' ('n term wat hierdie straf meer algemeen as die kerklike tug maak) is 'geestelijk' en word onderskei van die 'burgerlijk gericht of straf'. Tog skroom die DKO nie om, volgens Calvyn, 'n duidelike onderskeid tussen die doel en optrede van die kerk en die staat te maak nie. Hier is nie sprake van die sosiologiese terme en meer verfynde onderskeidings van NGKO 1998, artikels 59 en 65 nie, maar die vertrekpunt is daar (Pont 1981:184-185; Strauss 2010:126) selfs al sou gereformeerdes 
tans nie saamstem met alle onderskeidings, die oorsprong daarvan of dat sulke bepalings in ' $n$ kerkorde opgeneem word nie (Strauss 2010:109-117, 128).

In die res van sy artikels vir die kerklike tug (Pont 1981:184-186) bepaal die DKO hom tot sake soos die aard van tugwaardige sondes en tugmaatreëls - sake wat wye navolging in gereformeerde kerke vind wat uit die Nederlands-Dordtse stam sou groei (Engelhard \& Hofman 2001:429 e.v.; Visser 1999:261 e.v.). Omdat die DKO na die kerklike tug as 'geestelijk' verwys en dit van die burgerlike straf onderskei, vat hy die eie aard van die georganiseerde kerk raak. Vanuit hierdie geestelike karakter kom die pastoraal-kerklike aard van die kerklike tughandeling wat billik en regverdig is as ' $n$ natuurlike gevolg. Hierdie waarnemings maak NGKO 1998, artikel 59.3 'n geesteskind van die DKO, maar in 'n nuwe tyd. Op hierdie punt geld die woorde wat J.D. Vorster (1960:13) vir NGKO 1962 gebruik het ook vir artikel 59.3: NGKO 1998, artikel 59.3 is die DKO '... aangepas by die eise van die dag'. Anders gestel: die NGKO, artikel 59.3 is 'n geesteskind van die $\mathrm{DKO}$, artikel 71, maar in eie reg met eie beklemtonings.

Met sy aanduiding van die pastoraal-kerklike karakter van die kerklike tug en sy eis dat dit alles billik en regverdig geskied, kan NGKO 1998 vanuit die Skrif en 'n Christelike samelewingsleer gehandhaaf word. Die DKO, artikel 71-82 is nie hiermee in stryd nie-inteendeel. Dit konsentreer op ander sake omdat dit in ' $n$ ander tyd voorkom en nie die meer moderne Westerse samelewing ken nie. Wat die DKO wel aandui, is 'n onderskeid tussen, wat ons vandag noem, kerklike tug en die straf van die staat. Daarmee gebruik dit dieselfde vertrekpunt as NGKO 1998, artikel 59 en spesifiek artikel 59.3 soos dit ook in NGKO 2017, artikel 60.3 opgeneem is. NGKO 1998, artikel 59.3 gee egter ook 'n aanduiding van kerkordelike ontwikkeling en ' $n$ groei in insigte met betrekking tot die kerklike tug - sake wat in hierdie bydrae bevestig word.

\section{Erkenning \\ Mededingende belange}

Die outeur verklaar dat hy geen finansiële of persoonlike verbintenis het met enige party wat hom nadelig kon beïnvloed het in die skryf van hierdie artikel nie.

\section{Literatuurverwysings}

Bouwman, H., 1985, Gereformeerd Kerkrecht II, Kok, Kampen.

Calvyn, J., 1947, Commentaries on the epistle of Paul the apostle to the Romans, Eerdmans, Grand Rapids, MI.
Coertzen, P., 1998, Church and order, Peeters, Leuven.

Coertzen, P., 2003, 'Regsbeskerming in die kerk', in R. Torfs, K., Martens \& L.J. Koffeman (eds.), Recht op recht in de kerk, pp. 199-258, Peeters, Leuven.

De Jong, O.J., 1987, Geschiedenis der kerk, Callenbach, Nijkerk.

Donner, J.H. \& Van den Hoorn, S.A., s.j., Acta Nationale Synode te Dordrecht ten jare 1618 en 1619, Donner, Leiden.

Du Plooy, A. le R., 2007, 'Beginsels vir regspraak in die kerk', Die Kerkblad 110, (3198), 18-20.

Engelhard, D.H. en Hofman, L.J., 2001, Manual of Christian Reformed Church Government, CRC Publications, Grand Rapids, MI.

Fowler, S., 1988, The state in the light of the scriptures, PU vir CHO, Potchefstroom.

Jansen, J., s.j., De kerklijke tucht. Handleiding ten dienste van de Gereformeerde Kerken, Kok, Kampen.

Jonker, W.D., 1994, Bevrydende waarheid, Hugenote-Uitgewers, Wellington.

Kock, P. de B., 1975, Christelike Wysbegeerte - Inleiding, Sacum, Bloemfontein.

Kruger, L.S., du Plessis, H.L.M., Spoelstra, B. \& Spoelstra, T.T., 1966, Handleiding by die Kerkorde, Pro Rege, Potchefstroom.

Nauta, D., 1971, Verklaring van de kerkorde van de Gereformeerde Kerken in Nederland, Kok, Kampen.

Ned Geref Kerk in Afrika v Verenigende Gereformeerde Kerk in Suider-Afrika 1998 SA $536(\mathrm{HHA})$.

NG Kerk-Uitgewers, 1982, Ons glo ..., NG Kerk-Uitgewers, Wellington.

NGKO, 1962, Kerkorde van die Ned Geref Kerk, NG Kerk-Uitgewers, Kaapstad.

NGKO, 1998, Die Kerkorde, Hugenote-Uitgewers, Wellington.

NGKO, 2017, Die Kerkorde, Hugenote-Uitgewers, Wellington.

Plomp, J., 1969, De kerklijke tucht bij Calvijn, Kok, Kampen.

Plomp, J., 1992, 'Kerk en recht', in W. van't Spijker en L.C. van Drimmelen (eds.), Inleiding tot de studie van het kerkrecht, pp. 32-42, Kok, Kampen.

Polman, A.D.R., sa, Onze Nederlandsche Geloofsbelijdenis IV, T. Wever, Franeker.

Pont, A.D., 1981, Historiese agtergronde van ons kerklike reg I, HAUM, Pretoria.

Praamsma, L., s.j., Calvijn, Zomer en Keunings, Wageningen.

Rutgers, F.L., 1971, De geldigheid van de oude kerkenordening der Nederlandse Gereformeerde Kerken, Ton Bolland, Amsterdam.

Sadler, T.H.N., 1979, Die kerklike tughandeling, NG Kerkboekhandel Transvaal, Pretoria.

Sizoo, A., s.j., Johannes Calvijn Institutie III, Meinema, Delft.

Smit, C.J., 1984, God se orde vir sy kerk, NG Kerkboekhandel Transvaal, Pretoria.

Strauss, P.J., 1993, Op die tweesprong, UV, Bloemfontein.

Strauss, P.J., 1999, 'Die goedkeuring van kerkrade vir 'n nuwe verband in die NG Kerkfamilie?', Acta Theologica 19(2), 32-54.

Strauss, P.J., 2006, 'Die Dordtse tradisie en binding aan die belydenis', In die Skriflig 40/4, 560-575. https://doi.org/10.4102/ids.v40i4.363

Strauss, P.J., 2010, Kerk en orde vandag, SunMedia, Bloemfontein.

Strauss, P.J., 2015, Gereformeerdes onder die Suiderkruis 1652-2011, SunMedia, Bloemfontein.

Strauss, P.J., 2017, Die Kerkorde van die Ned Geref Kerk 2013: Kanaal of hindernis vir kerklike tug? Ongepubliseer.

Van de Beek, A., 1992, 'Hermeneutiek van het kerkrecht', in W. van't Spijker en L.C. van Drimmelen (eds.), Inleiding tot de studie van het kerkrecht, pp. 59-72, Kok, Kampen.

Van Dellen, I. en Monsma, M., 1967, The revised church order commentary, Zondervan, Grand Rapids, MI.

Veldkamp, H., 1975, Zondagskinderen II, T. Wever, Franeker.

Visser, J., 1999, Die Kerkorde in praktyk, EFJS, Orkney.

Vorster, J.D., 1960, 'Die Kerkorde van die NG Kerke - Besware daarteen en betekenis daarvan', Ned Geref Teologiese Tydskrif 1(4), 12-18.

Weijland, H.B., 1965, Augustinus en de kerklijke tucht, Kok, Kampen. 